\title{
THE URGENCY OF APPLYING JOURNALISTIC ETHICS IN ONLINE ISLAMIC MEDIA REPORTING ACTIVITIES: A CONCEPTUAL STUDY
}

\author{
Fitri, Adeni \\ Fakultas Dakwah dan Komunikasi \\ UIN Walisongo Semarang \\ Emailfitrifdk@walisongo.ac.id, adeni@walisongo.ac.id
}

\begin{abstract}
$T$ his article aims to study the urgency of applying journalistic ethics in online Islamic media activities. The study focuses on analyzing the seven standards of Islamic Media Literacy from Indonesian Ministry of Religion, namely (1) principles of online news production, (2) news distribution ethics, (3) accuracy and anti hoax, (4) the spirit of amar ma'ruf nahyi munkar, (5) principle of wisdom in da'wah, (6) principles in digital interaction, and 7) principle of press freedom. By using the qualitative method of library research, we argue that these seven principles could be said as journalistic ethics that must be applied in Islamic media reporting activities. These values are extremely important for Islamic media activities because the credibility of journalists and media institutions is related to public assessment which is quite determining the continuity of media life. The news in online Islamic media has different characteristics from other media. Online Islamic media cannot avoid how a text or symbol is presented in the category of fundamentalism-radicalism or moderate Islamic ideology. Problems arise when the radical Islamic ideology is more dominant than moderate Islamic ideology so that it is not uncommon for the Islamic media to get caught up in provocative actions which in some limits create disharmony for people's lives. If that is the case, the application of peaceful journalistic values becomes important to display Islamic da'wah of rahmatan li alamin.
\end{abstract}

Keywords: Islamic online media reporting, Journalism ethics, the seven standards of Media Literacy, News coverage. 


\begin{abstract}
ABSTRAK
A rtikel ini bertujuan mengkaji urgensi penerapan etika jurnalistik dalam aktivitas $\triangle$ media Islam online. Studi ini berfokus menganalisis tujuh standar Literasi Media 1 Islam dari Kementerian Agama Indonesia, yaitu (1) prinsip-prinsip produksi berita online, (2) etika distribusi berita, (3) akurasi dan anti tipuan, (4) semangat amar ma'ruf nahyi munkar, (5) prinsip kebijaksanaan dalam dakwah, (6) prinsip dalam interaksi digital, dan 7) prinsip kebebasan pers. Dengan menggunakan metode kualitatif berbasis penelitian kepustakaan (library research), kami berpendapat bahwa ketujuh prinsip ini dapat dikatakan sebagai etika jurnalistik yang harus diterapkan dalam kegiatan pelaporan media Islam. Nilainilai ini sangat penting untuk kegiatan media Islam karena kredibilitas jurnalis dan lembaga media terkait dengan penilaian publik yang cukup menentukan keberlangsungan kehidupan media. Pemberitaan di media Islam online memiliki karakteristik yang berbeda dengan media lain. Sebagai media yang tidak dapat dipisahkan dari sebuah ideologi, media Islam online tidak dapat menghindari bagaimana sebuah teks atau simbol ditempatkan dan disajikan dalam kategori ideologi fundamentalisme-radikalisme atau ideologi moderat Islam. Persoalan muncul ketika varian ideologi Islam radikal lebih dominan dari pada ideologi Islam moderat sehingga membuat media Islam tidak jarang menampilkan sikap provokatif, yang dalam batas tertentu menimbulkan dishormoni bagi kehidupan masyarakat. Olah karena itu, penerapan nilai-nilai jurnalistik damai menjadi penting dalam upaya menampilkan dakwah Islam yang rahmatan li alamin.
\end{abstract}

Kata Kunci: Pemberitaan Media Islam Online, Etika Jurnalisme, Tujuh Standar Literasi Media, Peliputan Berita. 
Fitri, Adeni

\section{INTRODUCTION}

The role of press (both online and conventional) is very important in public life. The press is one of the pillars of mass education, namely community empowerment through the mastery of information. Now press has appeared in online media form by the presence of the Internet. There is a lot of positive information spread by online media press. However there is still media containing hoaxes and provocation ranging from politics, social, health and even security (Pasrah, 2008, p. 118). Public needs to be careful in listening to or taking information from online media, especially those labeled as Islamic. It turns out that not all online Islamic media contains positive information, but instead contains negative messages. Online Islamic media also contains radical contents and hate speeches. This certainly obscures the Islamic view which calls for the excuse of ma'ruf nahy munkar and the existence of Islam as a peaceful religion (rahmatan lil alamin).

Abuse of online media was followed up by the government, precisely on March 31, 2015, the Ministry of Communication and Information blocked 19 internet sites that were indicated to contain radical contents (Musyafak, 2015, p. 1). This shows that press freedom is often misused by media. Journalists in implementing press freedom tend to forget or deliberately forget the rights of others to get correct information (Barus, 2015, p. 235). For this reason, journalistic ethics is needed as a journalists guide in carrying out activities in their fields. Journalistic ethics should be carried out so the news delivered to the public can be justified.
Hamdan Daulay (2008, p. 113) revealed that journalistic ethics has a high commitment to ethical values, namely regarding the values of right and wrong, what is permissible and what is prohibited. This is in accordance with Islamic values that are committed to the values of honesty, truth, and the prohibition of spreading false news, let alone spreading slander. The most severe disobedience to reporting on journalistic ethics occurs in online media. The flow of online media content is often not controlled by its managers so that it often violates ethics (Astraatmadja, 2015, p. 84). This can be found in online media uploads, such as false and inaccurate news. Journalistic ethics in reporting is needed because it is related to the benchmarks of good and bad journalistic activities, journalistic can be accepted or rejected by public (Yunus, 2012, p. 103).

Indonesian society, especially Muslims, is faced with a dilemma in the information age, namely the lack of adequate mass media to fight for and uphold Islamic values (Kasman, p. 5). This article attempts to answer how is the urgency of implementing journalistic ethics in the activities of Islamic online media reporting. The author tries to collect works related to the theme of the paper. Writing related to journalistic ethics, Islamic sites, and online media can be found as well as research: 1) "Journalistic Ethics Code and Press Freedom in Indonesia Judging from the Islamic Perspective" by Hamdan Daulay; 2) "Journalistic Code of Ethics and Press Freedom in an Islamic Perspective" by Heri Romli Pasrah; 3) "Radicalism Construction in Online Media: Case Study of Radical Site Blocking by the Ministry of Communication and Information" by 
The Urgency Of Applying Journalistic...hal.19-37

Najahan Musyafak (2015); 4) "Ideology of Indonesian Islamic Media in the Da'wah Agenda" by Choirul Mahfud; and 5) "Islamic Online Media in Multicultural Communities" by Eni Maryani and M. Fakhrudi Akbar (2013).

Unlike the previous works, the author in this paper aims to find out about reporting in online Islamic media, reviewing journalistic ethics and its urgency in online Islamic media. By using qualitative method focusing on library research, the author will elaborate the terms related to online Islamic media, reporting, and journalistic ethics. Therefore, this article is a conceptual study of the concepts of online Islamic journalism.

\section{DISCUSSION: ONLINE ISLAMIC MEDIA FOR JOURNALISM}

\section{Defining New Media, Online Media, and Internet}

The media, according to Shirley Biagi (2017, p. 6), is a plural form of medium which means the intermediary of a message to reach an audience. Media as a message channel is very commonly known in the study of media communication. It becomes a place where a message is constructed and channeled in relation to social reality. With this understanding, the media can be seen as an extension of ideas and thoughts towards social reality (Ibrahim, 2005, p. 455). On the other hand, Marshall McLuhan (1999) revealed the media was a message. He understands the media is more than just a tool to transmit messages. For him, the media is the message itself. By this understanding, the media is the culture and form of civilization of a society. The development of the media from one form to another becomes a justification for the McLuhan's theory.

Old media continues to be developed with the emergence of new media. In the context of old media, newspapers can only be read, radio can only be heard, and television only unites audio and visuals. New media unites everything that belongs to old media in which texts, sounds, and images can be put together through the Internet (David Holmes, 2004). Internet users can now read posts through blogs and websites, listen to radio through internet radio (streaming), and can watch news broadcasts via live streaming or download videos that are spread on YouTube. In other words, all the characteristics of each old media can be united in the world of new media (Tamburaka, 2013, p. 77).

The presence of new media is inseparable from the important role of the internet that provides online services. The term 'online' is a general terminology that provides an overview of the access, acquisition and dissemination of digital information. The internet is an infrastructure allowing computers to talk to each other around the world. Meanwhile, the Website is an interface that allows the exchange of various data, texts, images, graphics, messages, audio and video on the internet (Lukmantoro et al, 2014, p. 2). Online is understood as a state of connectivity refers to the internet or the world wide web (www). Online is an internet language which means information can be accessed anywhere and anytime as long as there is an internet network (Romli, 2012, p. 120).

Therefore, online media as a new form of media, according to Biagi (2010, p. 
231), is defined as all forms of communication combining texts, images, sound and video using computer technology and being connected to the internet. Digital media read, write and store data electronically in numerical form using number codes for data in the form of text, images, sound and video.

Internet technology basically contributes to creating media diversity. The internet provides free and open space for the emergence of online platforms in cyberspace. From the industry side, the cost of producing media and production equipment that is getting cheaper and more sophisticated has led to the emergence of mass media (Nasrullah, 2014, p. 1). Meanwhile, there is an unusually massive wave in the midst of society in carrying out activities through the media.

\section{Online Press/Journalism and Its Contents}

The term 'journalism' is etymologically derived from the French 'journ' or 'journal' which means daily notes or reports (Kusumaningrat \& Kusumaningrat, 2009, p. 15). Journalism can also be interpreted as a matter of reporting and journalism, therefore people who work for journalism are called journalists (Yunus, 2012, p. 17). Meanwhile, according to Dja'far $\mathrm{H}$. Assegaff, journalism is an activity to convey messages or news to public (mass) through media channels, both print and electronic media (Ardhana, 1995, p. 1). So basically journalistic activities are news activities carried out through various stages, such as the process of gathering, processing, and broadcasting
There is another term which is often equated with journalism, namely the press (Muhtadi, 1999, p. 25-26). The press is synonymous with matters relating to the media (intermediaries), while journalism is more a process of activity, namely the activities of searching, digging, gathering, processing, loading and spreading news through media periodically (Sumadiria, $p$. 1). Nevertheless, journalism and the press have a very related understanding.

The development of journalism can be seen from the presence of online media. What is attached to the characteristics of conventional journalism above also applies to online journalism. The difference between online journalism and other journalism (print and broadcast media), lies in its use. Online journalism is all journalistic activities with internet connection that connects journalists as the sender of various messages with the audience who plays as message recipients. Journalism does not change its meaning simply because it undergoes a form shift from conventional to online (Lukmantoro et al, p. 1).

Online journalism, also called cyber journalism, internet journalism, and web journalism. It is a new generation after conventional (print) and broadcast journalism. In the context of online media, news that appears is not published a few minutes, hours, days, or weeks, but as soon as events occur they can be processed directly and uploaded to the online media website. This is what makes online journalism different from journalism in other media (Suryati, p. 115). This form of journalism is conducted with online system that have the advantage of speed in reporting. 
The Urgency Of Applying Journalistic...hal.19-37

In addition, writing and airing online newsdiffers from writing in other media. Generally if online news is opened, at the beginning of the story, the title and lead or news intro appear. To find out more, the reader or netter (internet user) must open (click) the next page or link (Mondry, 2007, p. 156). Running news patterns in online reporting have the advantage of being able to reduce the public boredom in viewingnews, in addition to the limited lay out on the screen. Lack of this display, people must actively click on the news to finish the information loaded, sometimes they have to be patient if the internet connection has a problem.

Journalism has an extraordinary social function. According to F. Fraser Bond, journalism has several functions. First, to inform. Journalism is a means to convey information in the form of facts and events that occur around human life and should be known to public. Second, to interpret. Journalism is a means to provide interpretation of facts and events occurring so public can understand the impact and consequences of the news presented. Third, to guide. Journalism is a reference to direct or give instructions in responding to facts and events that are presented in the news so they can become public guidelines in giving opinions or making decisions. Fourth, to entertain. Journalism is an entertaining means, which is refreshing the reader by presenting the light and relaxed news or information according to the needs of the human lifestyle (Yunus, p. 20).

Activities of journalism is focusing on collecting information and producing it to become content. Content is information available in media. The information presented by online media is generally the same as print media such as newspapers or magazines, which consists of news, opinion articles (views), features, photos, and advertisements grouped by category (national, international, and other news categories). The contents of online media are generally divided into two parts, namely the page and category. Pages usually contain static information such as profiles (about us), guest books, or other important information. Categoryrubricating in print media or programs in electronic media is a groupingof writing typesin terms of topicssuch as national news, product information, opinion articles, features and tips. Readers are facilitated by the online systemin finding information. They can go directly to find the information with just clicking on the navigation menu guide of pages and categories(Romli, p. 35).

One part of the content is news. The etymological news comes from Sanskrit, that is vrit, some also call it vritta (an event or something that has happened) (Jonah, p. 45). In English it is called 'news' (Pareno, p. 2003, p. 5), which comes from Latin: novum; nova, which means new. In Islam, the term 'news' is called al-naba', al-khabar, and al-hadith, all of which correspond to the meaning of reporting (Kasman, 2010, p. 124). The Eastern Press has a different system from the Western Press. The Eastern Press does not view news as a commodity, news is not a commodity. News is a process with the determinable direction(Kusumaningrat \& Kusumaningrat, 2005, p. 32).

According to The New Grolier

Webster International Dictionary, as quoted by Kusumaningrat \& 
Kusumaningrat (p. 39), the news is (1) current information about something that has taken place, or about something not known before, (2) news is information as presented by a news media such as papers, radio, or television, (3) news is anything regarded by a news media as a subject worthy of treatment. Another definition was put forward by Mitchell V. Charnley, who sawnews as the timely report of facts or opinions that hold interest or importance, or both, for a considerable number of people. Meanwhile, David Randall defines news is fresh, unpublished, unusual, and generally interesting. Up to the point, as the word itself implies, news contains much that is new, informing people about somethingthat has just happened (Harcup, 2009, p. 41).

News production and construction is a collaborative process in which the team is united by the editor authority with the same values understanding and by an understanding of the roles in the team. The making news process is a process flowing from the first contact with the news source to the news appearing time on the page or screen. There are three stages: collection and selection, editing (further selection), and construction. The news gathering and editing process is fundamentally determined by the assumption of news making, on the subject matter and which treatments are valuable and which are not. This value can be expressed according to its importance to the society, but the value can also be seen as a benchmark of ideological importance (Burton, 1999, p. 110-111).

Every news comes from facts, but it still refers to news values. Not every fact is feasible and can be reported. Feasibility that shows the possibility of an event processed to be news, is called news values (Lukmantoro et al, p. 3). The event news worthy can be examined by assessing its properties. The assessment of news value is done by analyzing the consequences, human interest, prominence, proximity, and timeliness in a news item (Samantho, p. 112).

\section{Journalism of Islamic Online Media}

Lately, social movements are very often done through media. At this point the Islamic online media can become part of the channel for religious movements to sound the breath of Islam based on their ideological choices (Rusmulyadi, 2013, p. 13). Islam is able to show an identity through media, to distinguish it from other ideologies.

Islamic online media is a field of study that is not easy to study. The term presents the problem of making diverse definitions and study focus. There is no definitive definition of Islamic online media (Semati, 2011), but it is usually determined based on the elements of content, media ethics, and commitment to Islam (Ibrahim, 2005, p. 259). Referring to Aslam Abdullah who wrote about Muslim media, Islamic media can be interpreted as media for and about Muslims in particular and the Muslim world in general which are made from an Islamic perspective (Ibrahim, p. 261). In addition, viewed from the basic ideology of Muslim life oriented to the Qur'an and As-Sunnah (hadith) (Ansari, 2004, .pp. 170-171; Rusdi, 2015, p. 82), Islamic online media can be deeply learned from two ideological frameworks, namely fundamentalistm-radicalism and moderate 
The Urgency Of Applying Journalistic...hal.19-37

Fundamentalism-radicalism is

Islamic thought is strongly dominated by the fiqh (legal) formal thought oriented (Ali \& Effendy, 1986, p. 49). This group is a group that historically dominated the whole approach to the development of the interpretation of the Qur'an in the early days. Tafsir (Islamic interpretation), in this period until the Middle Ages even today, is using a textual, literal, normative approach. This approach has implications for scripturalist and formalistic thought products (Malik, p. 18).

Moderate ideology referred to modernization thought is identical or almost identical with the notion of rationalization, a process of reforming old thought patterns and work procedures that are not rational and replacing them with new thought patterns and work procedures that are genuine (Madjid, 1987, p. 208). The implications of this approach appear in the product of its cultural and substantial thinking (Malik, p. 19). Moderate can be interpreted as balanced, istiqamah, fair, and takes the middle or the middle way. The principle of moderate religion internally implies a wise and not rigid way of religion that views religious obligations as something that is in accordance with the nature of humanity. Moderate arises due to several factors. First, there is an order from every religion to glorify humans. Second, awareness of the oneness of God, Prophethood, and Humanity. Third, there is an awareness of the fact that world citizens mostly build life and nationality with a plural and multicultural reality (Harahap, 2011, p. 162). As an ideology, moderate Islam is a religious understanding that comes from authoritative religious texts, but able to adapt context and locality. It is a religious understanding that is oriented towards humanity and morality (Misrawi, 2010, p. 133). In the context of extremism which is associated with large currents of religious ideas indoctrination that are nuanced of violence and terrorism, moderate religious understanding is needed, especially in the era of technological media.

Islamic media has certain characteristics or conditions (Yusoff, 2016). First, Islamic media must be owned by Muslims, if their ownership is collective (for example, the shares of the relevant media companies have been traded publicly on the stock exchange), the majority of shares must be owned by Muslims. Second, the media must more or less carry the mission of preaching, namely the mission of glorifying the religion of God, spreading the values of Islamic teachings, advancing and educating Muslims. The values of Islamic preaching does not mean that the media must be solely filled with a collection of religious sermons or quotations of verses of the Holy Qur'an and the hadith of the Prophet. Third, Islamic media must apply the rules, ethics, and values of Islamic teachings, in carrying out the business of media companies and editorial activities (Arismunandar, 2013). The characteristics mentioned here find their shape in the framework of Hamid Mowlana (2014) who saw that the Islamic media centered on the open delivery of journalistic information to embody universal Islamic values.

The emergence of a number of religious media, especially Islam is one indicator of ongoing efforts to respond to society trends in religious life (Gholam, 2007). The atmosphere of religious life in 
Indonesia needs to get a positive response from various groups including the press. Problems concerning religious understanding, renewal of Islamic thinking, and people's aspirations will be easily assessed and approached through communication media (Muhtadi, 2015, p. 150).

The form of Islamic network media which can be seen from the name of an Islamic website or online site can be interpreted from the packaging of contents raised in the tag line, main menu, and headline. Based on these aspects, online Islamic media confirms its position as Islamic media (Maryani \& Akbar, 2013, p. 52). The advancement of Islamic media can be produced by professionals with high enthusiasm and dedication. Editors must be given creative freedom and editorial freedom to be able to present the news. Islamic media must be able to meet the curiosity of the people and the information presented is interesting and meets the needs of readers. Religious content clearly cannot be relied solely on the interests and norms that want to be loaded by the Islamic leaders (Ibrahim, p. 477). Islamic media should also accommodate the aspirations of people, other than as a conduit of information.

Islamic media should be developed with high journalistic quality. The media is the center of control, not only because of its technological capabilities that transcend space and time, but also because of the interrelationships that are inherent in communication, specifically its capacity to give individuals access to global networks. As a part of the rapid development of information technology, the presence of the internet along with the various sites or content in it not only changes individual behavior, but also influences even an increasingly globalized scale (Sugihartati, 2014, p. 95).

The news in online Islamic media is also not much different from other media. Whenever there is a difference, it lies in the labeling (Koroglu \& Tingoy, 2011). Generally labeling in Islamic media rests on the ideological orientation behind the Islamic media (Mahfud, p. 5). News in online Islamic media at least refers to variants of media ideology, namely fundamentalism-radicalism and moderate. The media/press may have various goals and expectations, but whatever is presented must not set aside the truth (Muhtadiah, 2017, p. 37). In addition, the message loaded must be in accordance with the principle of amar ma'ruf nahyi munkar. The constructivist perspective viewing the inseparability of social reality from the construction of thought must be translated by Islamic media in the form of a universal Islamic values construction.

\section{The Seven Islamic Media Literacy Standards of Indonesian Ministry of Religion as Islamic Journalistic Ethics: Lessons from al-Qur'an and Hadith}

The word 'ethics' comes from the Greek word 'ethos.' The singular form of the word ethos means ordinary dwelling, pasture, habits, customs, morals, feelings, ways of thinking. The plural form, ta etha means custom. Ethics in philosophical terms, means the science of what is commonly done or the science of customs (Mufid, 2009, p. 137). Ethics is often also called ethics. Ethics is a reflection of the community's view of what is good and bad, 
The Urgency Of Applying Journalistic...hal.19-37

as well as distinguishing acceptable

behavior or attitudes from what is rejected in order to achieve good inlife together. Ethics concerns social and cultural values that have been agreed upon by the society as the normsadhered together (Amir, 1999, p. 34). Stephen J.A. Ward defines ethics as the analysis, evaluation and promotion of correct behavior and or good character according to the best standards available (Nasution, 2015, p. 27). So journalism is an good and right value system that is obeyed.

Journalistic ethics is defined as part of applied ethics, which is examining what journalists and news organizations must do, given the role of the media in society. This includes editorial independence, verification, anonymous sources, use of altered graphics or images, and norms for new forms of media (WahlJorgensen, p. 295). Journalistic ethics can be interpreted as a system of values or norms that become a press reference in carrying out their duties and functions of journalism. Journalistic ethics is the ruleagreed upon and upheld by press members, both individualy and institutionally. The substance of journalistic ethics is to uphold the truth in implementation of journalistic tasks. The spirit prioritized in the implementation of journalistic ethics is to ensure that the press and mass media can still fulfill their social functions, in addition to the informative function, although journalistic ethics is made by the press members themselves (Yunus, 2012, p. 106).

Ethical issues of online journalism can be grouped into three groups. First, news gathering: journalists face conditions that require ethical considerations related to online media, such as journalists who hide their identities in chat rooms to record and quote posts from bulletin boards and disseminate them without permission. Second, news reporting: the internet increases the intensity of the competition to be first, while events are still developing and key facts are not yet known. Third, the presentation of news: the separation between editorial interests and the media business is often blurred because its main purpose is to survive or more dominantly business interests (Widodo, 2010, p. 45).

$$
\text { Journalistic ethics limits }
$$

journalists about what is good and what is not good being reported. The various formats of ethical guidelines that exist in press institutions or journalist organizations as well as in the Directorate General of Islamic Community Guidance (Indonesian Ministry of Religion) have similarities in terms of ethical values or principles used as guidelines in running journalism. Ethical principles are oriented towards the activities of journalists. Principles that guide journalistic ethics include accuracy, independence, objectivity or balance, fairness, impartiality, respect for privacy and accountability to the public (Nasution, p. 115).

In the context of online Islamic media, specifically the Directorate General of Islamic Community Guidance (Indonesian Ministry of Religion) has approved the Seven Standards of Islamic Media Literacy as a journalist reference and online Islamic media institutions. The agreement in the Media Literacy Standards covers a number of reporting aspects, ranging from news production, news distribution ethics, to the principles of da'wahand amarmakrufnahymunkar. What 
Fitri, Adeni

is stated in the seven standards is more accurately referred to religious ethics in media activities. Religious ethics comes from the religiosity concept that is nomerely in the sense of ritual worship but also in a broad sense which involves social life (Paremo, 2003, p. 118). The following will discuss the Seven Standards of Islamic Media Literacy.

\section{Principles of online news production}

Verification (tabayyun) of the accuracy of information and carefully checking the credibility of the sources producing a news is very important. This adopted the standard of science jarh wa ta'dildeveloped in the Hadith science tradition. Ensuring compliance with journalistic code of ethics in searching news materials and writing is a necessity. The method "take the clear, discard the murky," used as a handle in sorting out information in the middle of the flood of information in the new media era. A journalist needs to increase the comparison of various credible information sources, to get in-depth and complete information,including news sources in the form of a internet link (https://bimasislam.kemenag.go.id/post/beri $\mathrm{ta} /$ meeting-crew-media-islam-agreed upon -7-standard-literacy-media-islamic-online).

The Qur'an provides enough information on how information must be accurate. Accurate information can be obtained by tabayyun (check and recheck)technique. The accuracy of the information in this discussion is relevant to Surah Al-Hujurat verse 6.

"O you who believe, ifthe wicked is coming to you bring a message, then examine it carefully so that you do not inflict a disaster on a people without knowing the real condition, which causes you to regret your actions" (Department of Religious Affairs, 2010 , p. 516).

The verse came down to remind the Prophet to be careful about receiving information. Incorrect information used as a basis of making decisions will cause provocative decisions, and therefore the tabayyunis needed. Tabayyuncan be interpreted not to rush to receive information and be careful until the information is clear (Syahputra, 2007, p. 161). According to Al-Qurthubiy, verse 6 of Surah Al-Hujurat is an indication that information can be received from someone who is just. The information is trust. In addition to the issue of information accuracy, the credibility of information sources is also important. Fasiq people are not enough credible as carriers or providers of information (Syaputra, p. 162). Journalists are obliged to do filtering and selection (filtering and selecting) of the current rampant information. Not all information is good, true and useful for the community, especially Muslims. Information that is defamatory, hasud, or immorality must be examined and prevented from spreading to public. The function of research, screening and selection of information is known as tabayyun(Samantho, 2002, p. 68).

\section{Ethics of news distribution}

It must be ensured, the information to be distributed has to bring benefits and does not trigger slander. Not 
The Urgency Of Applying Journalistic...hal.19-37

all information received is immediately disseminated (the principle of: kafabilmar'ikadzibananyuhadditsa bi kulli ma sami'a, a person is simply declared a liar, if he preaches everything he hears). It is clear that if you cannot speak well, you should be silent (the principle of falyaqulkhairan aw li yashmuth). This principle must be a guide before spreading information in an era where news sharing is very easy. The rules of removing dhararand the preventive principle (dar'ulmafasidmuqaddam 'ala jalbilmashalih) need to be examined before spreading the news. Maintaining ukhuwah, by not appearing provocative and degrading, and insulting, because what is insulted can be more noble in the eyes of God (the principle of la yaskharqaumun min qaumin, 'asaanyakunakhair) (https://bimasislam.kemenag.go.id/ post / news / meeting-crew-media-islam-agreed7-standard-literacy-media-islam-online).

Muslim journalists as servants of God both as individuals and professions mustconvey and fight for the truth in every place and with all the consequences. When delivering their journalistic work, journalists should use good and correct language in polite and wise language styles, sowhat they convey will be understood, felt, and become wisdom for the public (Kasman, p. 67).

\section{Guarantee of the accuracy and commitment of anti-hoaxes}

Islamic media must be willing to 'hasanah' (role mode) in ensuring the honesty of information, in the midst of the invasion of lies, hoaxes and manipulative information (https://bimasislam.kemenag.go.id/post/beri
ta/perEMENT-media-crew-media-islam agreed-7-standard-literacy-media-islamiconline). The principle of accuracy means the substance, facts, and writing of news or other journalistic works written by journalists and broadcast by the media have to come from authoritative and competent sources of information, and are not biased(Nasution, p. 116). The honesty or objectivity aspect is ethics based on facts and data. Factuality is the key to honesty ethics. Writing and reporting is done honestly, not distorting the facts (Amir, p. 66). Real reporting, not lying, not influential and impartial is the key to journalistic success. An honest and proven truth reporting will be trusted by public. This certainly impacts both journalists as writers and the media of their work institutions.

\section{Spirit of amar ma'ruf nahyi munkar}

The principle of social control in journalism must be enthusiastic about calling for virtue and preventing munkar (https://bimasislam.kemenag.go.id/post/beri ta/pertasiswa-awak-media-islam-s-7-7standard-literation-media-islam-online ). Amar ma'ruf nahyi munkar are two forms of direct instruction from theQur'an, which at the same time cannot be separated. Calling for good is not appropriate in the wrong way, on the contrary preventing mungkar must also be done in an ethical manner (Syahputra, p. 147). Ma'ruf is the name for all the virtues or good qualities which have always been accepted by human conscience. While munkar is the name for all sins and evils which have been 
condemned by humans as evil all the time (Arifini, 2011, p. 121).

\section{The principle of wisdom in da'wah}

Journalists have to pioritize wise attitude, full of wisdom, good example, and even if it has to be a polemic, it is done in a better way. The character of interactivityand spontaneity of new media is prone to provoke friction if itis not accompanied by the principle of wisdom in calling for virtue, by avoiding prejudice and bad faith. This path is relevant in the midst of strengthening Islamophobia (https://bimasislam.kemenag.go.id/post/ news/crew-media-islamic-agreed-7standards-literacy-media-islamic-onlinemedia).

Wisdom in the practice of $d a^{\prime} w a h$ can be interpreted wisely in choosing approach soother people do not feel offended or feel that they are forced to accept a particular idea. Every missionary activity must lead to human consideration in all its aspects. Gentleness is inseparable in the way a person conveys his ideas to influence others (Tasmara, 1997, pp. 6667). The principle of wisdom in journalistic activities can at least ward off the bad image of Islam and show that Islam is rahmatan lil alamin.

\section{The principle of digital interaction:} Mutual respect and mutual assistance (ta'awun)

Concern for fellow Muslims in online media is very important (https://bimasislam.kemenag.go.id/post/ news / meeting-crew-media-islam-agreed7-standards-literacy-media-islamiconline). The virtual world (cyberspace) creates virtual communities or internet communities spread across various regions and even the world, and is free to conduct discussions and exchange information. Everyone can access useful messages without obstacles through the internet without knowing national borders (Arifin, p. 93). News in online media allows the audience or readers to interact with each other. Sympathy and empathy can be demonstrated by positive comments. Likewise with media crews, they can help each other to exchange information that is useful for society.

\section{The principle of press freedom}

The press freedom is expressed responsibly by upholding the moral and principle of "the best man is the most useful for his fellow human beings." Press freedom is managed by halaland thayyib efforts(Bimas Islam https://bimasislam. Kemenag.go.id/post/berita/ meeting-crewmedia-islam-agreed-7-standard-literacymedia-islamic-online). Freedom ofpress is the freedom to express ideas both information or news in the realm of journalism. This freedom is not absolutely free, but it is certainly bound by the existing norms or ethics. The function of the press is not only as a conduit of information, but also directly in contact with many people and social responsibility. Giving benefit to others is one of the principles in regulating social life according to Islamic teachings (Basiti, 2013 , p. 22). Therefore, in the freedom to meet the people needs, the press as a propaganda media must pay attention to Islamic values. This also affects the existence and credibility of the media/press, sothe messages contained can be received by society. Succes can not be separated 
The Urgency Of Applying Journalistic...hal.19-37

from the role of society, as a loyal audience visiting online media sites and providing constructive criticism.

Islamic press online activities can be guided by these seven principles in presenting Islam as a religion of da'wah. All Islamic media press activities (searching, digging, gathering, processing, loading and spreading the news) can pay attention to these signs. The most important thing is that the 7 standards lead to the formation of moderate Islamic media (wasatiyyah) that prioritizes the dissemination of information oriented towards peace and social harmony.

\section{The Relevancy of Journalism Ethics to Islamic Online Media Activities}

New media is increasingly finding its relevance to the universal Islamic teachings. Online Islamic media is needed in Islamic preaching activities, because this type of media can spread information and reach a wide audience and even the world. The globalization process of peaceful Islamic teachings to all people in the world can be done through online Islamic media (Khalil, 2016).

Da'wah in the context of cyberspace (online) is in line with the condition of people as the da'wahtarget in the current era of technological advancement and sophistication. However, preaching through online media not only requires media crew to have special skills in the field of journalism, but also a high commitment to the ethics of Islamic journalism. High commitment to ethics will produce good quality journalistic works in the form of news, features and articles that contain invitations or appeals about the importance of achieving success, achieving progress, doing good, and leaving humiliation and so on (Ardhana, 26).

The urgency of applying journalistic ethics to Islamic media rests on the fact that Islamic media is part of journalistic media, as other media. Communication media, without exception, including Islamic media must consider journalistic values/ethics in carrying out its mission (Amir, pp. 44-45). This is very important, because whole of journalism activities must involve society. High commitment in carrying out journalistic ethics will influence people to easily accept the existence of media. If the news presented by a media is not ethical, then of course the image of media will be bad. Vice versa, news that pays attention to and applies journalistic ethics will reflect the credibility of media (Yunus, p 107). The Islamic media has the opportunity to build its image as a peaceful medium. If not, the Islamic media and the practitioners will be judged to be contrary to their identity as carriers of peaceful Islamic mission. Therefore, Islamic media must be able to translate the mission of amr ma'ruf nahy munkar in a good and right way in accordance with the situation of society.

The above conditions have increasingly tightened the ethical urgency for Islamic media, especially when dealing with the authority to take roles in the delivery of various messages of da'wah (amr ma'ruf nahy munkar). In the context of internet media, Islamic da'wahcan be done or delivered by journalists or anyone (Arifin, pp. 89-90), even by those who do not understand religion. Everyone can play role as a preacher in the context of online media. This condition is very worrying for 
Islamic media when the message of Islam is not delivered by those who are not wise.

This is the way Islamic media should be. Islamic media must play a role in maintaining their orientation so they always side with the goodness, truth, and justice in accordance with human nature and endurance. Thus the Islamic media is faithful in carrying out its social responsibilities such as not broadcasting false news, not spreading pornography and not broadcasting sensations (Arifin, p. 96). Online Islamic media as a means of da'wah must be a positive information suggestion, or at least be a counterweight to the spread of negative content that often unsettles society.

At this time, by using sophisticated and affordable communication media, society can obtain information services very quickly. This also becomes a challenge and opportunity for Muslim journalists. But there are things need to be taken seriously in online Islamic journalistic activities in relation to the principle of speed and correctness of information. Speed is important in online journalism, but speed in delivering information is not the main thing. The truth of message delivered to people is more important. Prioritizing the truth of information increasingly finds its urgency when dealing with today's society which tends to prefer to consume information quickly and instantly.

As the main means of conveying and obtaining information, the existence of media is crucial for improving the quality of people in all fields of life through the dissemination of correct information. However, the public's right to obtain correct information is often not guaranteed because of conflicts of interest in politics, economics, and culture occurring in media (Haryatmoko, 2007, p. 19). There is a variety of provocative information that trigger conflict, because of the media partial interests. Therefore, correct information is a necessity. Appropriate information becomes an effective educational tool for society. Correct information can also prevent people from misunderstanding so it becomes an important means of creating peace.

\section{CONCLUSION}

The article concluded that the coverage in online Islamic media has different characteristics from other media. As a media that is inseparable from an ideology, online Islamic media cannot avoid how a text or symbol is placed and presented in the category of Islamic media ideology, it can be fundamentalismradicalism or moderate. Because of this ideological variant, Islamic media often appear to impose their ideology, which to some extent may be irrelevant to society. The emergence of da'wah media with extreme Islamic messages is one example of the existence of the Islamic media.

Therefore, attention to journalistic ethics is a necessity for Islamic media. Islamic media, although appearing with religious ideological messages, must still guide journalistic ethics in their activities. Islamic media activists must find and process the news, to spread it to the public based on ethical standards that have been mutually agreed upon. Specifically, the Directorate General of Islamic Community Guidance (Indonesian Ministry of Religion) has endorsed the Seven Standards of Online Islamic Media Literacy which includes the 
The Urgency Of Applying Journalistic...hal.19-37

principles of online news production, news distribution ethics, guarantee of accuracy and anti-hoax, spirit of amar ma'ruf nahyi munkar, principles of wisdom in preaching, principles in digital interaction, and the principle of press freedom. Journalistic ethics is very important to be applied by online Islamic media in reporting, because it influences the credibility of journalists, media institutions, and society. On the other hand, of course the character of Islam as a religion of peace must be proven through the construction of a reconciling media message.

\section{REFERENCES}

Ali, Fachry dan Bahtiar Effendy. (1986). Merambah Jalan Baru Islam (Exploring the New Way of Islam). Bandung: Mizan.

Amir, Mafri. (1999). Etika Komunikasi Massa dalam Pandangan Islam (The Ethics of Mass Communication in the Islamic View). Jakarta: Logos.

Anshari, Endang Saifuddin. (2004). Wawasan Islam: Pokok-pokok Pikiran tentang Paradigma dan Sistem Islam(Islamic Insight: Main Thoughts about Islamic Paradigms and Systems).Jakarta: Gema Insani.

Astraatmadja, Atmakusumah. (2015). "Wawancara Tokoh Pers." Jurnal Pers Indonesia. Edisi 8.

Barus, Sedia Willing. (2010). Jurnalistik: Petunjuk Teknis Menulis Berita. Jakarta: Penerbit Erlangga.

Biagi, Shirley. (2010). Media Impact: Introduction to Mass Media. Jakarta: Salemba Humanika.

Burton, Graeme. (1999). Media and Popular Culture. Yogyakarta: Jalasutra.

\section{$34 \quad \begin{aligned} & \text { Islamic Communication Journal } \\ & \text { Volume 5, Nomor 1, Januari-Juni } 2020\end{aligned}$}

Daulay, Hamdan, (2008). "Kode Etik Jurnalistik dan Kebebasan Pers di Indoensia Ditinjau dari Perspektif Islam."Jurnal Penelitian Agama, Vol.XVII, No. 2.

Effendy, Bahtiar dan Soetrisno Hadi. (2007). Agama dan Radikalisme di Indonesia (Religion and Radicalism in Indonesia). Jakarta: Nuqtah.

Hamad, Ibnu. (2004). Konstruksi Realitas Politik dalam Media Massa: Sebuah Studi Critical Discourse Analysis terhadap Berita-berita Politik. Jakarta: Granit.

Harcup,Tony. (2009). Journalism Principles and Practice: Second Edition. London: Sage Publications.

https://bimasislam.kemenag.go.id/post/berit a/pertemuan-awak-media-islamsepakati-7-standar-literasi-mediaislam-online.

Ibrahim, Idi Subandy. (2005). Media dan Citra Muslim: dari Spiritualitas untuk Berperang menuju Spiritualitas untuk Berdialog. Yogyakarta: Jalasutra.

Iswandi Syahputra. (2006). Jurnalisme Damai: Meretas Ideologi Peliputan di Area Konflik, Yogyakarta: P_Idea.

Juditha, Christiany. (2016).“Jurnalisme Damai dalam Berita Konflik Agama Tolikara di Tempo.co." Jurnal Penelitian Komunikasi dan Opini Publik, Vol. 20 No. 2.

Kasman,Suf. (2004).Jurnalisme Universal: Menelusuri Prinsip-prinsip Da'wah Bi Al Qalam dalam Al Quran. Jakarta: Teraju.

Kasman,Suf. (2010). Pers dan Pencitraan Umat Islam Di Indonesia: Analisis Isi Pemberitaan Harian Kompas dan 
Fitri, Adeni

Republika. Jakarta: Balai Litbang dan Diklat Kementerian Agama RI.

Khiabany, Gholam. (2007). "Is there an Islamic communication? The persistence of 'tradition' and the lure of modernity." 21 (1), Unisa Press. DOI: 10.1080/02560040701398814.

Khalil, Amal Ibrahim Abd El-Fattah. (2016). "The Islamic Perspective of Interpersonal Communication." Journal of Islamic Studies and Culture, Vol. 4, No. 2, pp. 22-37.

Koroglu, Osman \& Tingoy, Ozhan. (2011). "Principles Of Islamic Communication: A Comparison with Western Communication Approaches and Some Turkish Examples." World Congress on Islamic Systems 2011 (World-ISLAM2011), 28th - 29th November 2011, Holiday Villa Hotel $\&$ Suites, Subang, Malaysia.

Kovach, Bill\& Tom Rosenstiel. (2001). The Elements of Journalism. Jakarta: Institut Studi Arus Informasi dan Kedutaan Besar Amerika Serikat.

Kusumaningrat, Hikmat dan Purnama Kusumaningrat. (2005).Jurnalistik Teori dan Praktik. Bandung: Remaja Rosdakarya.

Lukmantoro, Triyono, dkk. (2014).Jurnalistik Online: Teori dan Praktik di Era Multimedia. Semarang: AJI Semarang dan Jurusan Ilmu Komunikasi Universitas Diponegoro.

Mahfud, Choirul. (2014). "Ideologi Media Islam Indonesia dalam Agenda Dakwah." Jurnal Dakwah Vol. XV, No. 1.

Malik, Hatta Abdul. (2014).Analisis Framing dan Ideologi Informasi Islam Situs eramuslim.com dan Voa- islam.com. Semarang: LP2M-IAIN Walisongo Semarang.

Maryani, Eni dan M. Fakhrudi Akbar. (2013). "Media Online Islam di Masyarakat Multikultur." Jurnal Communication Vol. 4 No.2.

Misrawi, Zuhairi. (2010). Pandangan Muslim Moderat. Jakarta: Kompas Media.

Mondry. (2008). Pemahaman Teori dan Praktik Jurnalistik. Bogor: Ghalia Indonesia.

Mowlana, Hamid. (2007). Theoretical Perspectives on Islam and Communication, China Media Research. 3 (4), 23-33. (Diakases pada 12 Maret dari http://www.chinamediaresearch.net).r ess, 2002).

Muhtadiah,Dian. (2017). "Peran Jurnalisme Profetik Menghadapi Hoax." Jurnal Dakwah Tabligh Vol. 18, No.2.

Mufid, Muhammad. (2009). Etika dan

Filsafat Komunikasi. Jakarta:

Kencana.

Muhtadi, Asep Saeful. (2012). Komunikasi Dakwah:Teori Pendekatan, dan Aplikasi. Bandung: Simbiosa Rekatama Media.

Musyafak, Najahan. (2015). Konstruksi Radikalisme Di Media Online: Studi Kasus Pemblokiran Situs Radikal oleh Kementerian Komunikasi dan Informatika. Semarang: LP2M UIN Walisongo Semarang.

Nasrullah, Rully. (2014).Teori dan Riset Media Siber (Cybermedia). Jakarta: Kencana.

Nasution, Zulkarimein. (2015).Etika Jurnalisme Prinsip-Prinsip Dasar. Jakarta: Raja Grafindo Persada. 
The Urgency Of Applying Journalistic...hal.19-37

Pasrah,Heri Romli. (2008). "Kode Etik Jurnalistik dan Kebebasan Pers dalam Perspektif Islam." Jurnal Dakwah Vol. IX, No. 2.

Pareno, Sam Abede. (2003). Manajemen Berita Antara Idealisme dan Terapan. Surabaya: Papyrus.

Rivers, William L dan Jensen, Jay W. (2003).The Mass Media and Modern Society. Jakarta: Kencana.

Romli, Asep Syamsul M. (2012). Jurnalistik Online: Panduan Praktis Mengelola Media Online, Bandung: Nuansa Cendekia.

Rusadi, Udi. (2015). Kajian Media: Isu ideologis dalam perspektif, Teori dan Metode. Jakarta: Raja Grafindo Persada.

Rusadi, Udi. (2015). Kajian Media: Isu ideologis dalam Perspektif, Teori dan Metode. Jakarta: Raja Grafindo Persada.

Rusmulyadi. (2013). "Framing Media Islam Online terhadap Konflik Keagamaan di Indonesia." Jurnal Komunikasi Islam, Volume 03, Nomor 01 Suf Kasman. (2010). Pers dan Pencitraan Umat Islam di Indonesia : Analisis isi pemberitaan harian Kompas dan Republika. Jakarta: Balai Litbang dan Diklat Kementerian Agama RI.

Satrio Arismunandar, (2013). "Media Islam atau Media Islami dan Perbedaannya."Muslimmedianews.co $\underline{m}$, edisi 10 Agustus 2013, diakses 12/08/2017.

Semati, Mehdi. (2011). "Communication, Culture, and the Essentialized Islam." Communication Studies, 62:1, 113126 , DOI: 10.1080/10510974.2011.540975.
Sugihartati, Rahma. (2014). Perkembangan Masyarakat Informasi dan Teori Sosial Kontemporer. Jakarta: Kencana.

Suryawati, Indah. (2011).Jurnalistik Suatu Pengantar: Teori dan Praktik. Bogor: Ghalia Indonesia.

Sari, Fitri Meliya. (2014). "Analisis Penerapan Kode Etik Jurnalistik pada Harian Serambi Indonesia." Jurnal Interaksi, Vol.3No.2.

Syah, Hakim. (2012). "Peran Jurnalisme Islam di Tengah Hegemoni Pers Barat dalam Globalisasi Informasi." Jurnal Komunikasi Islam, Vol.02No. 1.

Syah, Sirikit. (2012).Membincang Pers, Kepala Negara, dan Etika Media. Jakarta: Elex Media Komputindo..

Syahputra, Iswandi. (2007). Komunikasi Profetik: Konsep dan pendekatan. Bandung: Simbiosa Rekatama Media. Tamburaka, Apriadi. (2013). Agenda Setting Media Massa. Jakarta: Raja Grafindo Persada.

Tasmara,Toto, (1997). Komunikasi Dakwah. Jakarta: Gaya Media Pratama.

Wibawa, Annisa Aninditya, dkk. (2012). "Etika dan Prinsip Jurnalisme Media Siber Detik.com Mengenai Mekanisme Pemberitaan Tewasnya WNI di Kerusuhan Mesir."Jurnal Mahasiswa Universitas Padjadjaran, Vol.1, No.1.

Widodo,Yohanes. (2010). "Menyoal Etika Jurnalisme Kontemporer: Belajar dari Ohmy News." Jurnal Aspikom, Vol.1, No.1.

White, Aidan. (2008). To Tell You The Truth: Ethical Journalism Initiative. 
Brussels: International Federation of Journalists.

Yunus, Syarifudin. (2012). Jurnalistik Terapan. Bogor: Ghalia Indonesia.

Yusoff, Sofia Hayati. (2016). "Western and Islamic Communication Model: A Comparative Analysis on a Theory Application."Journal of Islamic Social Sciences and Humanities, Vol.7, pp. 7-20. 